These four studies succeed in different ways with quite different analytical problems and cases. They also share two strengths that I would like to highlight. First, they are cautious about generalizing from a single case. Instead (and more usefully!) these studies make arguments and present information which help us understand more about the range of differences that can be found among social movements. Second, they often give us a sense of the action which carries their movement forward and in a sense is the movement. They do not just point to a movement's enabling organization or culture. These studies recognize that social movements continually face the problem of putting organization and culture into action. If you agree that studies with exactly these qualities are needed to advance sociologists' understanding of social movements, the articles which follow will serve you well.

\title{
References
}

Blumer, Herbert. 1939. "Collective Behavior." Pp. 221-280 in An Outline of the Principles of Sociology, edited by Robert E. Park. New York: Barnes \& Noble Inc.

Hostetler, John A. 1993. Amish Society. 4th Edition. Baltimore: The Johns Hopkins University Press.

Hostetler, John A. and Gertrude Enders Huntington. 1996. The Hutterites in North America. 3rd Edition. Fort Worth, Texas: Harcourt Brace College Publishers.

Huber, Thomas M. 1981. The Revolutionary Origins of Modern Japan. Palo Alto: Stanford University Press.

Kraybill, Donald B. 1994. "Plotting Social Change Across Four Affiliations." Pp. 53-75 in The Amish Struggle with Modernity. Edited by Donald B. Kraybill and Marc A. Olshan.

Tarrow, Sidney. 1994. Power in Movement. New York: Cambridge University Press.

\section{AMERICAN CULTURE THROUGH AMISH EYES: PERSPECTIVES OF AN ANARCHIST PROTEST MOVEMENT*}

\author{
THOMAS W. FOSTER \\ The Obio State University at Mansfield \\ MARS/Social Thought \& Research, 1997, Vol. 20, No. 1-2
}

\begin{abstract}
America's Old Order Amish have managed to avoid some of the most serious social problems facing the larger society. This paper identifies the countercultural and anarchistic elements of Amish society and outlines its resemblance to social movements and to other separationist/pacifist societies of the past. Also explored are Amish attitudes toward materialism, technology, art, deviant behavior and non-violent resistance and bow these attitudes shape internal social behaviors as well as interactions with outsiders. Finally, brief consideration is given to the question of bow the study of the Amish might inform students of the larger culture and other interested outsiders.
\end{abstract}

\section{Introduction}

America's 150,000 member Amish minority (Kraybill and Nolt 1995) has been almost uniquely successful among the nation's religious and ethnic groups in resisting change and in preserving the social integration of their small communities. Remarkably, the Amish have also managed to avoid most of the major social problems facing industrial society. Their adult crime rates are almost non-existent and their suicide rates were found to be the lowest of that of any rural-dwelling religious group in the Lancaster, Pennsylvania area (Kraybill, et. al. 1986). There is no welfare dependency in their communities because the Amish follow a tradition of "taking care of our own." The elderly are not placed in nursing homes but typically live with their children or grandchildren, usually in additions that are affixed to the houses of younger generations. The Amish do not accept public assistance or crop subsidy payments from government and they have been specifically exempted from the

- Direct all correspondence to Thomas W. Foster, Department of Sociology, The Ohio State University Mansfield, 1680 University Drive, Mansfield, $\mathrm{OH} 44906$. 
Although the Amish could be termed a society of "high school dropouts" by the standards of the larger culture, (because they attend school only through grade 8 ), there is practically no illiteracy among them. This despite the fact that most Amish children go to one or two room rural parochial schools and are taught by Amish teachers who themselves have only eighth grade educations (Hostetler 1993). In addition, young Amish men can almost always find employment, either within their own communities or in Mennonite or "English" owned enterprises. The willingness of many employers to hire Amish workers, even during periods of high unemployment, is related to their wellknown commitment to the work ethic, to their traditional craft skills and oftentimes, to their acceptance of lower than average wage scales.

Except for some alcoholism, there is almost no adult drug abuse in Amish communities. Neither are illegitimacy nor family disintegration commonplace. Nevertheless, the Amish do face a number of challenges to their traditional ways of life-and Amish lifestyles carry their own kinds of stresses and problems. Pressures for change have been especially intense in those settlements that have experienced the expansion of the larger society into areas that were once predominantly Amish and agricultural, e.g., Lancaster County, Pennsylvania or Geauga County, Ohio. Some of the pressures affecting settlements include the external influences of urbanization, industrialization and tourism and the internal influences of high rates of population growth, coupled with a related movement out of farming and into factory work. Today, only about half of Amish household heads are farmers and, in some settlements, fewer than a third farm, with many others being employed in non-traditional occupations. Although farming remains by far, the most widely preferred occupation among young Amish men, the increasing scarcity of affordable farmland, which has been exacerbated by urban sprawl, has forced the acceptance of other occupations (Foster 1984; Kraybill and Nolt 1995).

Many in the Amish community believe that factory work contributes to defections from the faith among their youth. (About 15-20\% of persons born Amish leave their communities before joining the church but the Amish population continues to grow rapidly due to a birthrate of about seven children per family). An Amish leader recently told me that there had been several (unprecedented) divorces in the Geauga settlement during the past two years, all of which had involved Amish men who worked in factories and who had entered into relationships with non-Amish female coworkers. Despite such problems, most observers believe that Amish culture will survive well into the foreseeable future, although certainly not without some forms of accommodation and change. While Amish society should not be romanticized, nor viewed as a utopian ideal, its ability to largely avoid most of the social problems confronting modem America, i.e., crime, suicide, welfarism, homelessness, family breakdown, unemployment, illegitimacy, drug dependency, social class conflict, illiteracy, etc., should be acknowledged as the extraordinary phenomena that it is - and one that merits close attention and careful investigation on the part of social scientists.

\section{Purpose}

We can learn a great deal about ourselves by studying cultures that are different from our own. And within the United States, there are few are different from our ow much from the American mainstream as that of the rural-dwelling, German-speaking Amish.

Hostetler has referred to the plain people - a category which includes the Amish - as a "counter society" (Redekop and Hostetler 1977:269) and Kraybill also views the Amish as being countercultural, writing that "the quilt of Amish culture is upside down in many ways... (defying) the taken for granted assumptions of modemity" (1989:44).

In my own work on the Amish, I have further developed the notion that the Amish are a countercultural movement, theorizing that they belong to a broad category of similar movements which have appeared and reappeared throughout history in response to the social crises of civilizations, i.e., that they represent a subtype of religious anarchist society (Foster 1987). My purposes here are, (1) to briefly explain why the Amish are countercultural anarchists and, (2) to detail some of the the Ams in which their culture views the values and institutions of the larger society.

\section{Conceptualization and Interpretation}

The picturesque peaceful Amish, with their dark archaic clothing and their quaint horse-drawn buggies are perhaps one of the last American minorities that one might, upon superficial acquaintance, associate with the terms "countercultural" or "anarchistic." Rather, one might be more inclined to conceive of the Amish as being religious fundamentalists who are also politically conservative and folk-like. But une apear to be. They are neither religious fundamentalists, nor politically conservative, nor a fitting example of a folk culture. 
For example, unlike religious fundamentalists, the Amish, who refer to themselves simply as Christians, do not proselytize, do not announce that they have been "born again" (they believe that God alone knows who has achieved salvation) and they do not, under any circumstance, condone the use of deadly force against other human beings, either by individuals, legal institutions or governments.

While some fundamentalists view the Amish as being a misguided sect whose members stand in need of being "born again," the Amish see the fundamentalists as being excessively prideful, overly-emotional and too much given to verbalizations of piety instead of good works. Because the Amish strongly distrust religious emotionalism, individualism, and above all, charismatic styles of preaching, they try to keep their young people strictly away from such fundamentalistsponsored activities as revival campaigns, Sunday Schools and Bible study classes which, in the past, have, at times, led to conversions and defections. The style of Amish church services is, in fact, almost the antithesis of that of fundamentalist churches; while the latter services are emotionally charged, very verbal, cathartic and, to some degree, individually expressive, the former are emotionally restrained, punctuated by periods of silence, predictable and ritualized.

Such considerations have led some scholarly observers to conclude that the Amish more closely resemble introspective mystics than they do religious fundamentalists (Plancke 1986). The Amish mistrust of words and their use of what Hostetler $(1980,1989,1993)$ has termed the silent discourse, both in their religious services and in everyday situations, reflect an almost Zen-like acceptance of silence and inaction as being appropriate ways of dealing with certain of life's problems and paradoxes.

Taking Christ's Sermon on the Mount as a literal moral credo, the Amish have historically refused to participate in the military services of various nations as combatants. Following the mass migration of Amish from Europe to the United States during the 18th and 19th centuries, the Amish won the right to serve in the military as non-combatant conscientious objectors. However, some conscripted Amishmen have continued to choose the option of imprisonment during wartime, rather than accepting altemative service as conscientious objectors (Hostetler
1989).

The Amish have also attempted to minimize their involvement with the larger society's legal system which violates their beliefs in two respects: (1) it attempts to employ force to secure conformity to its norms and, (2) it requires the swearing of oaths in courts of law.
"Going to law", as the Amish say, runs counter to the submissive spirit of nonresistance that undergirds their culture. Kraybill and Nolt write that:

"Filing a lawsuit is cause for excommunication. Although the Amish have reluctantly appeared in court to defend their principles or to test government regulations, they oppose plaintiff litigation and will not initiate lawsuits. . The Amish commitment to nonresistance and their dependence on divine solutions make them uncomfortable with a legal system that rests on coercive force" (1995:182).

Despite the absence of police, courts or prisons, Amish communities are almost free of adult crime and their members are often reluctant to become involved with the larger culture's criminal justice system - as complainants or witnesses - even when they are victimized by outsiders. Although the Amish seldom violate criminal laws, with the exception of selective service rules that carry criminal penalties, they have at times chosen to violate civil edicts and administrative regulations which they have interpreted as contradicting their beliefs or traditions. The rejection of law as a general means of social control by the Amish, in favor of custom, which is created by the members of local communities, puts them squarely in league with the antilegal perspectives of such ancient anarchists as Lao Tse and with such modern political anarchists as Kropotkin (Foster 1987). Furthermore, their rejection of the use of force, together with their support of a strict separation of church and state, separates the Amish, on the one hand, from most religious fundamentalists, and on the other hand, from nearly all political conservatives.

Using a folk model to characterize the Amish is equally inappropriate. The folk model is inappropriate because folk societies are characterized by non-rational, or irrational, conformity to traditional norms, whereas the members of Amish communities rationally evaluate proposed innovations in the light of their traditional values. To borrow Weber's term, the Amish typically engage in Wertrational action, which means that they do employ reason but they employ it so as to achieve value-determined goals. For instance, in the process of evaluating a new technology or a proposed social practice, members of Amish church communities publicly analyze and discuss the probable consequences of adopting the innovation before arriving at democratically-ratified community decisions. If the adoption of an innovation is seen by the members as being destructive of their cultural values, or as being disruptive of the human organization of their small communities, it will be rejected, despite the fact that it might offer a more efficient means of accomplishing work or of achieving some instrumental goal. Innovations are not rejected by the Amish merely because they are "modern", 
however, and they have accepted a number of technologies that they believe will not adversely influence their lifestyles (Foster 1984; Olshan 1980).

The wellspring and continuing inspiration for Amish anarchism is religion, and is to be found in the Anabaptist interpretation of the Holy Bible. Two of the most important biblical passages for Anabaptists are the scriptural admonitions to "Be not conformed to this world" and to "Be not unequally yoked to unbelievers" (Hostetler 1993).

Being unconformed to the world means, to the Amish, that they are obliged to seek conformity to the norms of Christianity and to the role model provided by the life of Jesus. Yet it is left to each church district to develop its own specific interpretations of precisely how to be different, e.g., in matters of local technological adaptations, permissible occupations, allowable places of residence, and so on. These matters become included in the ordnung, or democratically-formulated rules of the church community, and, as such, provide a certain amount of needed local flexibility. The ordnung also helps to account for differences in practices between Amish church districts. (If these differences become sufficiently great, they can lead to a situation in which church districts are "not in full fellowship," that is, in which their members are not permitted to attend each others' church services). However, the ordnung of an Amish community is more than a product of its members' local and practical concerns. It must also be guided by the general principles of Anabaptist theology and, to a lesser extent, by the historical traditions that have evolved among the Amish during centuries of political and religious persecution. While a detailed explanation of Anabaptist theology and Amish traditions lies beyond the scope of this paper, it is important to understand that the Anabaptist perception of Jesus diverges radically from that of mainstream Christian denominations and stands at the center of most Amish beliefs and practices. The Anabaptist vision of Jesus is that of a rebel, an anarchist Christ whose nobility springs from his rejection of the very things which the world values most. Jesus represents the humble beggar-king, whose spiritual stature is enhanced by his deliberate choice of the "low road", that is, by his conscious decision to follow a spiritual, rather than a worldly, path (Foster 1987; Plancke 1986).

The Amish continue to believe that each person should, upon reaching adulthood, consciously decide for themselves which path they intend to follow. If the path is that of a spiritual life, they will undergo baptism and join the Amish church-community, but if it is that of a worldly life, they will be obliged to leave their communities and to curtail, or to severely limit, their social interactions with their families.
(The Amish sometimes say, when queried by persons who wish to know if outsiders may ever join their faith, "No one is ever born Amish. We have all chosen this life. Those who choose to live as we live and to confess their faith will be welcomed.") Despite the fact that outsiders can become Amish, conversions by "seekers" rarely occur and the Amish are likely to react to inquiries from non-Amish persons with skepticism. A fairly typical Amish response to someone who wished to join the faith was, "Forget it, for most who try get more trouble than it's worth" (Hostetler 1993:398). The basis for such Amish skepticism is their doubt that worldly persons possess the self-discipline required for life in a spiritual community. "This life would be too hard for someone not raised in it," a 30 year old Amishman told me, adding, "I have met only three people who made the change."

The practice of the ban and of shunning reflect the longstanding Anabaptist belief that Jesus chose to live among believers rather than unbelievers ("Be not yoked to unbelievers") and that the individual church member and his or her concerns are of less importance than the welfare of the collective church-community. The norms which govern the placing of persons under the ban, or of shunning persons whose behavior has transgressed the rules of the ordnung, are not fixed and universal but vary according to the relative liberality or conservatism of various Amish subsects, settlements and church districts.

The model that the Amish look to for the size, organization, and relational style, of their communities is that of the relationship between Jesus and his disciples. The model is that of a gemeinscbaft culture, a culture emphasizing close and intense primary group relationships. Ideally, it becomes the basis for a small community of love, an extended family, which has no need for rigid bureaucratic hierarchies, formal laws or authoritarian edicts. Many of the ideals of small ecologically-balanced communities that were articulated by Schumacher in Small is Beautiful (1973) have been put into practice by the Amish, although it is doubtful that many Amish persons have ever heard of Schumacher. I have elsewhere described how the social organization of Amish communities empirically demonstrates the workability of many of Schumacher's "ecoanarchist" principles (see, for example, Foster 1981). (The hallmarks of Schumacher's ideal conserver society include: smallness of scale, community self-sufficiency, self-governance, escape from fossil fuel dependency, population decentralization, freedom from consumeroriented education, freedom from structural unemployment and the use of appropriate technologies.)

Appropos of smallness, Kraybill and Nolt have remarked: 
From egos to organizational units, the Amish prefer small-scale things. They fear that bigness will lead to pride and the abuse of power. Smallness also encourages
informal social relationships. The bureaucratic structures and formal procedures that proliferate in modern society are completely missing in Amish life (1995:9).

The internal solidarity of Amish communities is further strengthened by the fact that nearly everyone engages in manual occupations, resulting in a minimal division of labor and specialization. ("By the sweat of thy brow wilt thou earn thy bread"). Although most Amish families continue to exercise control over the instruments of production which generate their incomes, i.e., as self-employed farmers, craftspersons, or businesspersons, the same is not true for those Amish who are employed by outsiders. While this difference has not yet led to the formation of distinct social classes, some observers consider it possible that class distinctions could develop among the Amish in the future. A growing source of social and economic divisiveness is the recent, and very rapid, proliferation of successful home-based Amish businesses. These "microenterprises," according to Kraybill and Nolt, are socially transforming Amish culture "by encouraging individualism as well as a rationalized approach to life, with its concomitant accessories of efficiency, calculation and control" (1995:16). The movement out of farming and toward entrepreneuriship is not a wholesale capitulation, however, because there still exist a variety of cultural controls that mitigate against the large-scale development of business, e.g., church restrictions on acceptable technologies, prohibitions against litigation partnerships with outsiders, commercial insurance and higher education (Kraybill and Nolt, 1995:17)

The Amish are not historically unique as a type of culture but find their counterparts in other religious anarchist societies with pacifist and separationist leanings. One finds similarities, for example, between the Amish way and the ancient Taoists of China, the Moslem Sufis of Persia and the Gnostic Christians of Europe. In each instance, these peaceful anarchists tended to non-violently reject the formal institutions, laws and technologies of large-scale bureaucratized civilization in favor of the informal morality and the simple technologies of small-scale sacred communities. Oftentimes, as with the Amish, or their Anabaptist cousins, the Hutterites, these groups have been persecuted by bureaucrats and government officials and have been forced to seek sanctuary in remote and inhospitable regions. Here, they often developed close relationships with the natural world as well as unique strategies of agricultural survival (Foster 1987). While some of the most striking - if unlikely - cultural parallels are to be found between the ancient Taoist followers of Lao Tse and the Amish followers of Jacob Ammann (Foster 1987; Plancke, 1986); it is not difficult to find examples of modem thinkers who are representative of the latter version of anarchism. Among the best-known may be counted Thoreau, Tolstoy, and Schumacher. Joll, who has written extensively on the nature of anarchist societies throughout history, agrees that there were anarchistic tendencies within the Anabaptist movement in Europe during the Reformation period. Moreover, without specifically naming the Amish, Joll describes a type of anarchistic society that closely fits the contemporary Amish model:

\begin{abstract}
. Any heresy which demands a withdrawal from the world implies a criticism of the world's values and, moreover, the very act of withdrawal, especially if it led to the establishment of a group of like-minded devotees, often involved those who practiced it in measures which might seem dangerously subversive $(1966,18)$.
\end{abstract}

\section{Are the Amish a Social Movement?}

The continuing growth of Amish society, both in terms of total population increase and in terms of increasing church district memberships "like-minded devotees," suggests that the Amish share at least some of the qualities of successful social movements. In this regard, Redekop and Hostetler have commented that the plain people, like other social movements, "have demanded changes in the social order" and have shared "an ideological base normally religious in orientation" (1977:268). However, these writers have also pointed out that other social movements tend to undermine the reasons for their existence when they are successful, while the plain people are engaged in a type of "permanent protest." This permanent protest, moreover, expresses itself, not so much in actions directed toward the larger society that are designed to change it, but, rather, in actions that are internally directed, i.e., toward the development of a sacred community. Redekop and Hostetler concluded that there "seems to be a less dialectic relationship to the larger society than is normally the case with social movements" and that "once the plain people have emerged, they become a social/cultural phenomenon which is less responsive to the environment than is normally the case with social movements" (1977:268). To these observations, I will only add that the extent of the Amish protest against secular civilization has seldom been equaled by other social movements. Rather than being directed toward a single issue or a particular set of social institutions, the Amish protest has become generalized to include nearly all of the core values, institutions, norms and technologies of the dominant culture.

Amish Values and Mainstream American Values 

values and those of the American mainstream culture. The differences could hardly be more pronounced and they contribute to the deep and institutionalized sense of alienation which the Amish feel toward the secular urban society. While such differences do help the Amish in preserving their cultural boundaries and beliefs against the invasive forces of modemity, they have also contributed to culture conflict and, at times, to persecution by the larger society as the following examples and materials should illustrate. I have (somewhat arbitrarily) chosen to focus upon Amish values involving materialism, technology, art, deviant behavior and non-violence to demonstrate the extent of the schism that exists between the Amish and "English" world views.

\begin{tabular}{|c|c|}
\hline \multicolumn{2}{|c|}{$\begin{array}{l}\text { Table } 1 . \quad \text { Old Order Amish Values } \\
\text { and Mainstream American Values }\end{array}$} \\
\hline AMISH VALUES & MAINSTREAM VALUES \\
\hline $\begin{array}{l}\text { - Spirituality (material } \\
\text { simplicity, avoidance of } \\
\text { advertising, intense } \\
\text { involvement in the } \\
\text { religious community) } \\
\text { - Conformity (to community } \\
\text { standards) } \\
\text { - Separation from the Secular } \\
\text { World (in dress, language, } \\
\text { education, occupation, } \\
\text { residence, etc.) } \\
\text { - Humility (calm, } \\
\text { cooperative, placing others } \\
\text { first) } \\
\text { - Self- control (self- } \\
\text { discipline, emotional } \\
\text { restraint) } \\
\text { - Social control by customary } \\
\text { and religious norms } \\
\text { - Pacifism (rejection of use } \\
\text { of force by individuals and } \\
\text { legal and military } \\
\text { institutions) } \\
\text { - Decentralized political } \\
\text { democracy } \\
\text { - Rejection of bureaucratic } \\
\text { hierarchies (no } \\
\text { bureaucracies) } \\
\text { - Tendency toward } \\
\text { community self- } \\
\text { sufficiency } \\
\text { - Voluntary simplicity as a } \\
\text { desirable lifestyle } \\
\text { - Conservation and saving } \\
\text { orientation } \\
\text { doing things "naturally", } \\
\text { etc.) Use of appropriate } \\
\text { technologies } \\
\text { - Ecological ethos (living in } \\
\text { harmony with nature, } \\
\text { - }\end{array}$ & $\begin{array}{l}\text { - Assertiveness/aggres- } \\
\text { siveness } \\
\text { - Self- expression } \\
\text { - Social control by legal } \\
\text { norms } \\
\text { - Legitimized use of force } \\
\text { to ensure conformity } \\
\text { by legal and military } \\
\text { institutions } \\
\text { - Centralized political } \\
\text { democracy } \\
\text { - Society of bureaucratic } \\
\text { hierarchies } \\
\text { - Tendency toward } \\
\text { society- wide } \\
\text { interdependence } \\
\text { - Complexity, variety and } \\
\text { change as desirable } \\
\text { - Consumption and } \\
\text { spending orientation } \\
\text { - Use of centralized } \\
\text { technologies } \\
\text { - Instrumental ethos, } \\
\text { exploitation of nature }\end{array}$ \\
\hline
\end{tabular}




\section{Materialism}

While many Americans regard the Amish as being materialistic, e.g., "They have money but they don't spend it," or "They drive a hard business bargain," the Amish think of the "English" as being materialistic and wasteful. This is because Amish communities set limits upon such things as wages, prices and the amount of land that a family may own, while there are no comparable limits placed upon the earnings or holdings of non-Amish persons. Even those Amish families who operate their own businesses are subject to the control of their community regarding such matters as the nature, size and operational methods of businesses. The material simplicity of the typical Amish home reflects the belief that outer simplicity is linked to inner spirituality. The Amish also attempt to shield their children from the various forms of media advertising to prevent the development of a consumer mentality. Toward this end, contemporary magazines as well as radio and television sets, are not to be found in Amish homes and Amish food stores may repackage cereal or other foods if the original packaging contains advertisements.

An interesting example of how differently the two cultures view material incentives occurred during the making of the Paramount movie "Witness" in Lancaster county Pennsylvania in the summer of 1984. Because the filmmakers wanted to film some of the movies' scenes on an authentic working Amish farm, they offered financial remuneration to any Amish landowner who was interested. There were no takers. Paramount then publicly offered $\$ 260,000$ for the use of an Amish farm as a film site. Not one Amishman agreed (Parsons 1986). The Amish were so troubled by the fact that the Pennsylvania Bureau of Motion Picture and TV Development had solicited Paramount Pictures to shoot on location in Lancaster that they took the unusual step of sending a delegation of bishops to the state capital to register a protest to the Lieutenant Governor (Kraybill 1989). The Amish protested that they had not even been consulted about the film. Kraybill (1989) writes that the moviemakers violated Amish beliefs in three ways: first, they had always opposed films, photography and television; second, they had traditionally avoided publicity, and third, Hollywood symbolized worldliness, sex and violence in the Amish mind. In the meeting one of the bishops reportedly mentioned that the Amish might move entirely out of Lancaster County if the state could not assure them that other films would not be made in the future without their consent. After two subsequent meetings with state officials, a promise was extracted from the state that stipulated, among other things, that Pennsylvania would refuse to deal with film companies that attempted to film the Amish without their consent or to trespass on their property (Kraybill 1989). However, it was too late to stop the filming of Witness, which was successfully completed and which became a big box-office success, grossing some $\$ 37.7$ million in its first six weeks and increasing tourism to Lancaster County during that period by 13 percent (Kraybill 1989).

\section{Technology}

The car stands as a towering icon of American culture. But to the Amish the automobile symbolizes the triumph of technology over the religious and moral values that sustain communities and families. Although they do not consider cars to be evil in themselves, and will therefore accept rides in motor vehicles belonging to others, the Amish (excepting the small Beachy subsect) believe that permitting the ownership of cars by their people would allow their youth to escape the necessary social controls of community and family, and would encourage youthful deviant behavior.

Other technologies are rejected by the Amish if they are perceived to foster dependence upon "the world". For instance, being connected to high-wire electricity or to gas lines furnished by public utility companies is generally verboten, although some church districts do permit the use of natural gas in Amish homes if the supplying wells are also located on Amish-owned properties.

Most - but not all - of the technologies that the Amish use may be termed appropriate or intermediate, as Schumacher (1973) defined this term. Among other things, this means that technologies can be locally fabricated or obtained by nearly anyone, that they are relatively inexpensive and that they do not damage the natural environment or harm the humanity of those who employ them. Examples of appropriate technologies used by the Amish include windmills, waterwheels, and horse-drawn farm equipment.

Berry, who has written extensively about Amish agriculture, has said that by subordinating technology to their values the Amish have:

\footnotetext{
...become the only true masters of technology. They are mostly farmers, and they do most of their farm work by hand and by the use of horses and mules. They are pacifists, they operate their own local schools, and in other ways hold themselves aloof from the ambitions of a machine-based society. And by doing so they have maintained the integrity of their families, their community, their religion and their way of life. They have mastered one of the fundamental paradoxes of our condition: we can make ourselves whole only by accepting our partiality, by living within our limits, by being human-not by trying to be gods (1977:95).
} 
By rejecting the use of technologies that require centralized control, the Amish have simultaneously been able to prevent the growth of private or public bureaucracies within their society. The strong mistrust of centralized power and authority by the Amish - and the related absence of any large hierarchical organizations within their culture seems to be an outgrowth both of their historical persecution by governments over the centuries and by their anarchistic interpretations of Christianity.

In any event, a story told by Monroe Beachy, an Amishman who lives near Sugarcreek, Ohio, provides a good insight into the Amish attitude toward technology - and what it means to be Amish.

Well, let me tell you a story: Some time ago a group of fifty-two people chartered a bus and came to Holmes county to see the Amish. They had arranged to have an Amishman meet them and answer some of their questions.

The first question was: "We all go to church," and they named some of these churches, "so we know about Jesus, but what does it mean to be Amish?"

The Amishman thought a bit and then he asked a question of his own. "How many of you have TV in your homes?" Fifty-two hands went up. "Now, how many of you feel that perhaps you would be better off without TV in you homes" Again fifty-two hands went up. "All right. Now, how many of you are going to go home and get rid of your TV?" Not one hand went up!

Now that is what it means to be Amish. As a church, if we see or experience something that is not good for us spiritually, we will discipline ourselves to do without. 1989:272)

The world in general does not know what it is to do without! (Hostetler

Art

The Amish exercise strict control over various forms of artistic expression in their communities. Some art forms are entirely prohibited for instance, the playing of musical instruments, as well as dancing and photography. Painting is permitted if the subjects are "natural", i.e., animals, landscapes or farm settings. There are no individual portraits or sensual depictions of human forms (in drawings or paintings) and often the work is done on slate or wood (or even) on a sawblade, rather than on canvas.

The singing of hymns, in German, is encouraged during "visiting Sundays," which alternate with "church Sundays." There is no musical accompaniment during "singings" and the songs are taken from the Ausbund, which is the oldest known Protestant hymnal in existence. The hymns often recount the sufferings of Christian martyrs and are sung in a slow and plaintive manner.
Folk arts flourish among the Amish but these, e.g., quilt-making, embroidery or furniture-decorating, tend to be quite stylized and do not much reflect the individualized imprint of the artist's personality.

The Amish attitude toward art is a response to their belief that depicting the human form is an expression of pride and egotism. Humility, not pride, is the personality ideal. In more conservative Amish homes, even calendars depict only natural scenes or landscapes and bathroom mirrors tend to be smaller or are partially taped over.

\section{Deviant Behavior}

Amos Troyer is a 60 year old Amish farmer of my acquaintance whose family suffered a tragedy some 15 years ago when their buggy was struck by a drunk driver. One child was killed outright, another remains in a wheelchair and a third is now in his twenties but was left permanently brain-damaged and mentally retarded.

Once, Amos said, "The modern world is always in a hurry, always rushing but it's headed nowhere important. When you're going down the highway in your buggy, the cars come up behind you fast, real close, and some honk their homs. Maybe one goes fast around you then it just runs into a driveway and stops. Why?" He continued, "The alcohol and drugs are getting worse but putting people in jail won't stop it. They ought to burn down all those expensive prisons because you can't force people to be good. Youngsters learn to be good in their families and churches but these are not respected today. That is why we try to keep ourselves separate from the world." "But what," I asked, "would be done with all of the criminals if there were no prisons to hold them." Amos replied, "I'm not sure, but I think people need to be taught that if they commit harmful acts, they ought to be ashamed of themselves...they need to be trained to feel guilty when they're in the wrong. Children need to develop a conscience. They had a good idea back in Colonial times when they put peoples' hands and feet in the stocks and flogged them. It made criminals feel ashamed but afterward they could go home to their families and that was less cruel and costly than today's prisons. Of course, there are some people you can't shame into obedience - we (Amish) have asked these kinds of people to leave our communities. Why couldn't you send these sorts of people to a Devil's Island somewhere?"

\section{Non-Violence and Civil Disobedience}

While non-violent resistance to government authorities is apt to be associated, in the modern mind, with the teachings of Thoreau or 
Gandhi, or their followers, the Amish have long practiced non-violent civil disobedience based upon their understanding of the teachings of Jesus. Although they are generally among the most law-abiding of people, the Amish have historically refused to obey laws that they have interpreted as violating their Christian beliefs. For example, in the past, the Amish refused to comply with laws enforcing compulsory high school attendance and many parents were jailed, or had their properties confiscated, until the U.S. Supreme Court granted an exemption, in 1972, in the case of Yoder v. Wisconsin. Other historical examples of civil disobedience include Amish non-conformity to the Social Security and Selective Service Systems, and more recently, to local building and zoning ordinances, some of which have made it difficult for the Amish to establish home-based businesses.

The Martyr's Mirror is a sacred Amish text that recounts the tortures and executions of thousands of early Christians and Anabaptists. As part of the Anabaptist revolt against the established church and state during the Reformation period in Germany, Holland, and Switzerland, the Amish were severely persecuted and eventually, driven entirely out of the Continent, where none remain today.

An often-quoted and telling story from the Martyr's Mirror communicates the Amish ideals of non-violent resistance, altruism and martyrdom. In the story, Dirck Willems, a Dutch Anabaptist, is fleeing from religious persecution and arrest by local authorities in 1569 . In an effort to escape, he runs across a frozen lake. He is closely pursued by a sheriff but the sheriff falls through the lake's thin ice and cannot regain his footing. Willems returns and rescues the sheriff, knowing that he will be burned at the stake for his efforts. Following the rescue, the weeping sheriff delivers Willems to a certain fate at the hands of his executioners (Foster 1987).

A more contemporary and mundane example of how the Amish react to provocations by outsiders was recently recounted to me by a faculty colleague.

I was standing outside a small general store in Amish country, near Berlin [Ohio], when I noticed a well-dressed American family of four dive, near Berlin their late model station wagon. The family consistedy of four drive up and park younger teen-aged boys. After they got out of their car, the family gathered around an empty Amish buggy that was parked at the far end of the store parking lot. To my surprise, the father asked his family to get into the buggy, which they did, and the father began snapping pictures while the others posed, which they in holding the reins, and pretending to drive. Several minutes laking turns Amish couple emerged from the store and witnessed minutes later, a young their buggy. They merely the store and witnessed the photo-taking session in patiently for the "English" to to within a few feet of the buggy and waited without offering an apology or even acknowledging the Amish couple's buggy
These people acted as if the Amish were period actors at Disneyland. I couldn't help but wonder what would have happened if the shoe had been on the other

foot and the Amish had climbed into the tourists' car.

What motivated, and what continues to motivate, acts of martyrdom among the Amish? According to Kraybill, "the solution to the riddle of Amish culture is embedded in the German word Gelassenbeit" (1989:25). Gelassenheit has many meanings: submission, yielding to God and to others, resignation to God's will, a humble and surrendered spirit, modesty, obedience, self-denial, simplicity, dedication, contentment (Kraybill 1989).

\section{Kraybill states:}

The blood of martyrs seared Gelassenbeit into the sacred text of Amish history... The nonresistant stance of Gelassenbeit forbids the use of force in human relations... (and) Gelassenbeit_confirms that Amish culture is indeed a counterculture whose core values collides with the heartbeat of modernity, individual achievement (1989:25-26).

\section{Discussion}

The foregoing examples of Amish cultural perspectives have emphasized areas in which Amish values and beliefs diverge from those of the mainstream culture. This approach was employed to illustrate that the Amish are, in fact, anarchistic counterculturists, and to place Amish culture within a broader sociohistorical context of anarchist societies. However, it should be pointed out that there are certainly other areas in which the two cultures converge. For example, despite their general mistrust of law, the Amish hold the U.S. Constitution and the Bill of Rights in high esteem because these documents have furnished the basis for the greater degree of religious and political freedom which they have enjoyed in America. Likewise, the Amish do believe in the right of government to exact taxes from citizens and, contrary to much popular opinion, they do pay federal, state, and local, taxes. Nevertheless, the essence of being Amish is being "different from the world" and of being a people "who live in this world - but who are not of this world." That is why I have focused here upon cultural differences, instead of similarities. Berry (1977) has attributed the ability of the Amish to largely avoid the problems facing industrial society to the countercultural values of the Amish (anti-materialism, pacifism, separationism) and to their successes in socializing their children and defending their cultural boundaries. However, in recent decades, the growing scarcity of affordable farmland has put economic pressure upon Amish communities that has forced unprecedented cultural accommodations and occupational changes. For example, while factory work for outside employers would have been a 
cause for excommunication 40 years ago, today, factory employment is commonplace in many Amish settlements (Foster 1984). Another threat to traditional Amish values is the more recent large-scale occupational movement into commercial microenterprises that has been described by Kraybill and Nolt (1995). The latter, like factory work, brings church members into frequent and continuing contact with non-Amish persons and social institutions, as well as promoting materialism and other secular values. Despite such challenges to their lifestyles, the Amish have historically proven themselves to be capable of adapting to a wide variety of external changes and conditions, consistently confounding the past predictions of those social scientists who once regularly forecast their imminent cultural demise! Under these circumstances, it would seem best to admit that the on-going dialectic between the Amish and the world has often taken unexpected turns and that, while the survival of Amish society seems assured well into the future, the specific directions that the dialectic may take remains largely unpredictable.

But what lessons, if any, can the larger culture take from the example of the Amish? Perhaps, most importantly, the Amish society demonstrates a wide range of often unappreciated possibilities to American society. For instance:

That it is humanly possible to develop a workable economic system that is not based upon the principles of universal greed and material enrichment.

That it is possible for moral values to take precedence over technological "progress" and economic gain.

That it is possible for people to actually veto the acceptance of new technologies or social practices that offer comfort or convenience.

That it is possible to socialize most children into moral and altruistic behaviors.

That it is possible for a society to avoid the development of a consumer mentality.

That community life is still possible and that it is possible for communities to solve most of their own problems.

That it is possible to limit the growth of governmental bureaucracies.

That it is possible to prevent the forces of modemity from engulfing all cultures and subcultures that stand in their path.

That it is possible for appropriate technologies to be effectively and profitably employed, both in agriculture and in small enterprises.
That it is possible for a peaceful society to exist without laws, lawyers, police or prisons.

That it is possible to teach people self-discipline and to habituate them to living within community-imposed limits.

That it is possible that the individual and his or her personal goals are not the supreme reality.

And so forth. Yet can any of these seemingly utopian possibilities find successful forms of expression beyond the confines of Amish communities? The answer is that the Amish have for years served as useful models to the outside world in several different respects and areas. I will briefly mention only three of these areas. First, there is outsider interest in- and emulation of - Amish agricultural techniques. Agricultural scientists, conservationists and advocates and practitioners of sustainable farming have all been involved in studying and/or applying Amish farming methods. While it is impossible to know how often Amish techniques have been emulated by others, it is noteworthy that Amish methods of soil conservation, crop rotation and organic pest control are popular and recurring topics in American farming and gardening journals. A second, closely related area of outsider interest, is the Amish employment of energy-saving, non-polluting appropriate technologies (Foster 1987; Hostetler 1993; Kraybill 1989 1995). Frequent articles in international ecology, sociology, environmental, development and farming journals, i.e., pertaining to the Amish use of windpower, waterpower, animal power and (even) solarpower attest to a diverse and wide-ranging public interest in these topical areas, particularly in European nations and in regions with high energy costs. Third, there is the more recent focus of outsiders upon the often dramatic successes of the Amish in establishing small enterprises and home-based businesses (Kraybill and Nolt 1995).

It is perhaps ironic that a people that has mainly sought cultural separation from the world has so often found itself to be the subject of media and public attention. Yet it is also an Amish ideal that the faithful should serve as "a light unto the world" and that the best way to change the world is through example rather than exhortation.

\section{References}

Berry, Wendell. 1977. The Unsettling of America: Culture and Agriculture. New York: Avon Books. 
Foster, Thomas W. 1984. "Separation and survival in Amish society." Sociological Focus 17:1-15.

Foster, Thomas W. 1987. "The Taoists and the Amish: kindred expressions of ecoanarchism." The Ecologist 17: 9-14.

Hostetler, John A. 1993[1.980]. Amish Society. Baltimore: The Johns Hopkins University Press.

Hostetler, John A. 1989. Amish Roots: A Treasury of History, Wisdom and Lore. Baltimore: The Johns Hopkins University Press.

Joll, James. 1966. The Anarchists. New York: Grosset and Dunlap.

Kraybill, Donald B., J.A. Hostetler and D.G. Shaw. 1986. "Suicide patterns in a religious subculture: the Old Order Amish." International Journal of Moral and Social Studies 1: 249-262.

Kraybill, Donald B. 1989. The Riddle of Amish Culture. Baltimore: The Johns Hopkins University Press.

Kraybill, Donald B. and Steven M. Nolt. 1995. Amish Enterprise: From Plows to Profits. The Johns Hopkins University Press.

Olshan, Marc A. 1980 "The Old Order Amish as a model for development." Ph.D. Dissertation, Cornell University.

Parsons, William T. 1986. "The pemicious effects of Witness upon plain-worldly relations (in) Werner Enninger et. al. Internal and External Perspectives on Amish and Mennonite Life. Essen: Unipress.

Plancke, Fritz. 1986. "The Amish way: a Taoist approach" (in) Werner Enninger et. al. Internal and External Perspectives on Amish and Mennonite Life. Essen: Unipress.

Redekop, Calvin W. and John A. Hostetler. 1977. "The Plain People: an interpretation." The Mennonite Quarterly Review 51:266-277.

Schumacher, E.F. 1977. Small is Beautiful: Economics as if People Mattered. New York: Harper and Row.

\section{IDEOLOGY AS RESPONSE: CULTURAL AND POLITICAL PROCESS IN THE SANCTUARY MOVEMENT}

\author{
COLLEEN GREER \\ Bellevue University
}

MARS/Social Thought \& Research, 1997, Vol. 20, No. 1-2

\begin{abstract}
This paper examines the ideology of the Sanctuary Movement on behalf of Salvadoran and Guatemalan refugees displaced by domestic turmoil and war. This movement coalesced in the United States in the 1980s out of disparate efforts to assist particular refugees. Three interpretations of the role ideology are assessed: ideology as a resource for pursuing interests; ideology as a value system informing grievances; and ideology as sociallyconstructed frames realigned through discourse. It is found that core aspects of the ideology of the Sanctuary Movement emerged as individuals and church congregations came to terms with the needs and actions of those they belped and the U.S. government's opposition. Much of the ideology of the Sanctuary Movement was worked out by participants as they acted after the movement was underway. Analysis of $i d e o l o g y$ as a response is essential to relate the Sanctuary Movement to both the broader political culture and the political process with which it engaged.
\end{abstract}

\section{Introduction}

Recent work in the area of social movements and collective behavior has challenged the examination of social movements as formally structured organizations which function primarily on the basis of the existence or nonexistence of resources, and has moved the discussion toward a reexamination of the actor, the social context; and the sociopolitical culture within which social movement action is embedded. Central to these discussions is an effort to reexamine how actors link action and meaning to the broader culture. For example, how is it that encounters within an environment are framed, analyzed, and tied to themes of rights, freedom, individualism, protection, and economics? 